\title{
Subject Continuance
}

National Cancer Institute

\section{Source}

National Cancer Institute. Subject Continuance. NCI Thesaurus. Code C82523.

An indication or description that a subject will proceed with a particular course of action. 